\title{
Photochemical Studies of Solanum Melangena (Eggplant) Fruit by Flame Atomic Absorption Spectrometry
}

\author{
Rayann Persid, Vishwa N. Verma* \\ Department of Chemistry, Faculty of Natural Sciences, University of Guyana, \\ Turkeyen Campus, Georgetown, Guyana, South America \\ *E-mail address:professorverma@ymail.com
}

\begin{abstract}
Solanum melangena (eggplant) belongs to Solanaceae family. The common name of this frui and the plant is the same. It has different names in different countries such as eggplant, brinjal, baigan, balangie etc. Eggplant has been reported as a healthiest fruit due to the chemical constituents. The shape, size and colour of the fruits are also different. The genetically engineered eggfruits are also available. Some research works on eggplant are reported in different countries for different purposes. The present study has been taken into an account for the chemical elements present in flesh, skin and the seeds of eggplant grown in the soil and environmental conditions of Guyana. The investigation by the flame atomic absorption photometry shows the presence of $\mathrm{Ca}, \mathrm{Cd}, \mathrm{Co}, \mathrm{Cu}, \mathrm{Fe}, \mathrm{Mg}, \mathrm{Mn}, \mathrm{Pb}$ and $\mathrm{Zn}$ at a varying concentrations in flesh, skin and seeds. In general the presence of calcium and magnesium as the higher values out of which concentration of calcium is $1366 \mathrm{mg} / \mathrm{kg}$ in skin and magnesium as $2466 \mathrm{mg} / \mathrm{Kg}$ in seed.
\end{abstract}

Keywords: Solanum melangena; Eggplant; Elemental Analysis; AAS

\section{INTRODUCTION}

Solanum melangema belongs to Solanaceae family. The common name for the plant and the fruit is the same. The eggplant is known by different names in different countries as brinjal (England), baigan (India), balangie (Guyana) and many more names all over the world. There are now genetically engineered eggplant. The skin of the eggplant is of many colours but the purple, green and white are more common.

Eggplant is used for treatment of many diseases, including diabetes, arthritis, asthma and bronchitis as reported [2]. Research has focused on an anthocyanin phytonutrient found in eggplant skin called nasunin which is a potent antioxidant and free radical scavenger that has been shown to protect cell membranes from damage but at the same time it has also been reported that the eggplant contain measurable amount of oxalates which develops problems in kidney and gallbladder [3,4]. 


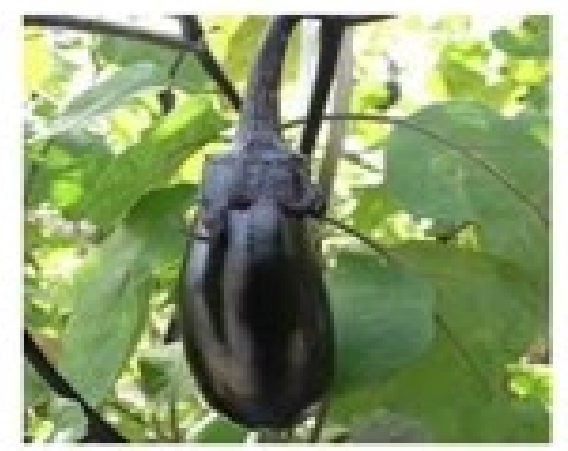

Fig. 1. Eggplant Fruit.

Distribution of hydroxycinnamic acid conjugates in fruit of eggplant is reported in literature [5]. Changes in the chemical composition of eggplant fruits during development and ripening have been reported with some changes [6]. The following table shows the high rating of the eggplant fruit for many chemical constituents. The photochemical studies for similar vegetables such as Cucurbitae Maxima [7] and Cucurbitae pepo [8] are also available in literature.

Table 1. Showing some nutrients in eggplant fruit.

\begin{tabular}{|c|c|c|c|c|}
\hline \multicolumn{5}{|c|}{$\begin{array}{l}\text { Eggplant, cubed, cooked } \\
1.00 \text { cup } \\
99.00 \text { grams } \\
\text { Calories: } 35 \\
\text { GI: low }\end{array}$} \\
\hline Nutrient & Amount & $\begin{array}{l}\text { DRI/DV } \\
(\%)\end{array}$ & $\begin{array}{l}\text { Nutrient } \\
\text { Density }\end{array}$ & $\begin{array}{l}\text { World's Healthiest } \\
\text { Foods Rating }\end{array}$ \\
\hline fiber & $2.47 \mathrm{~g}$ & 9.9 & 5.1 & very good \\
\hline vitamin B1 & $0.08 \mathrm{mg}$ & 6.7 & 3.5 & very good \\
\hline copper & $0.06 \mathrm{mg}$ & 6.7 & 3.5 & very good \\
\hline manganese & $0.11 \mathrm{mg}$ & 5.5 & 2.9 & good \\
\hline vitamin B6 & $0.09 \mathrm{mg}$ & 5.3 & 2.8 & good \\
\hline vitamin B3 & $0.59 \mathrm{mg}$ & 3.7 & 1.9 & good \\
\hline potassium & $121.77 \mathrm{mg}$ & 3.5 & 1.8 & good \\
\hline folate & $13.86 \mathrm{mcg}$ & 3.5 & 1.8 & good \\
\hline vitamin $\mathrm{K}$ & $2.87 \mathrm{mcg}$ & 3.2 & 1.7 & good \\
\hline \multicolumn{2}{|c|}{$\begin{array}{l}\text { World's Healthiest } \\
\text { Foods Rating }\end{array}$} & \multicolumn{3}{|c|}{ Rule } \\
\hline \multicolumn{2}{|c|}{ excellent } & \multicolumn{3}{|c|}{$\begin{array}{c}\text { DRI } / \text { DV }>=75 \% \text { OR } \\
\text { Density }>=7.6 \text { AND DRI } / \mathrm{DV}>=10 \%\end{array}$} \\
\hline \multicolumn{2}{|c|}{ very good } & \multicolumn{3}{|c|}{$\begin{array}{c}\text { DRI } / \mathrm{DV}>=50 \% \text { OR } \\
\text { Density }>=3.4 \text { AND DRI } / \mathrm{DV}>=5 \%\end{array}$} \\
\hline
\end{tabular}


Table 2. Daily requirement of the elements.

\begin{tabular}{|c|c|c|c|c|c|}
\hline Elements & Amount & Elements & Amount & Elements & Amount \\
\hline $\mathrm{Ca}$ & $1300 \mathrm{mg}$ & $\mathrm{Cr}$ & $35 \mathrm{mcg}$ & $\mathrm{Cu}$ & $900 \mathrm{mcg}$ \\
\hline $\mathrm{Fe}$ & $8 \mathrm{mg}$ & $\mathrm{Mg}$ & $320 \mathrm{mg}$ & $\mathrm{Mn}$ & $1.8 \mathrm{mg}$ \\
\hline $\mathrm{Ni}$ & $1 \mathrm{mg}$ & $\mathrm{Na}$ & $2.3 \mathrm{~g}$ & $\mathrm{Se}$ & $400 \mathrm{mcg}$ \\
\hline $\mathrm{Zn}$ & $8 \mathrm{mg}$ & & & & \\
\hline
\end{tabular}

Recommended by Institute of Medicines, Food and Nutrition Board (mcg = microgram)

\section{EXPERIMENTAL}

\section{1. Description of experiment}

The eggplant fruit was collected from a farm in lot 340 Union No 30 village, West Coast Berbice, Guyana. It was washed with deionized water. The skin, flesh and seeds were Separated carefully using a plastic knife. $5 \mathrm{~g}$ fo flesh, $5 \mathrm{~g}$ of seed and $5 \mathrm{~g}$ of skin were in separate crucibles in an oven keeping thetemperature around $100^{\circ} \mathrm{C}$. The seeds took about 30 minutes, the skin took about one hour and flesh took about 2 hours to dry.

The powder of these dried samples were prepared separately using the mortar and pestle. $1.0 \mathrm{~g}$ of the powder was digested into aqua regia (mixure of $\mathrm{Conc}$. $\mathrm{HCl}$ and Conc. $\mathrm{HNO}_{3}$ in the volume ratio of $3: 1$ ) i.e. $75 \mathrm{ml}$ conc. $\mathrm{HCl}$ acid and $25 \mathrm{ml}$ conc. $\mathrm{HNO}_{3}$ acid in a conical flask. Then it was placed on a heater on a temperature of $50{ }^{\circ} \mathrm{C}$ so that it can dissolve properly. It took neraly 40 minutes.

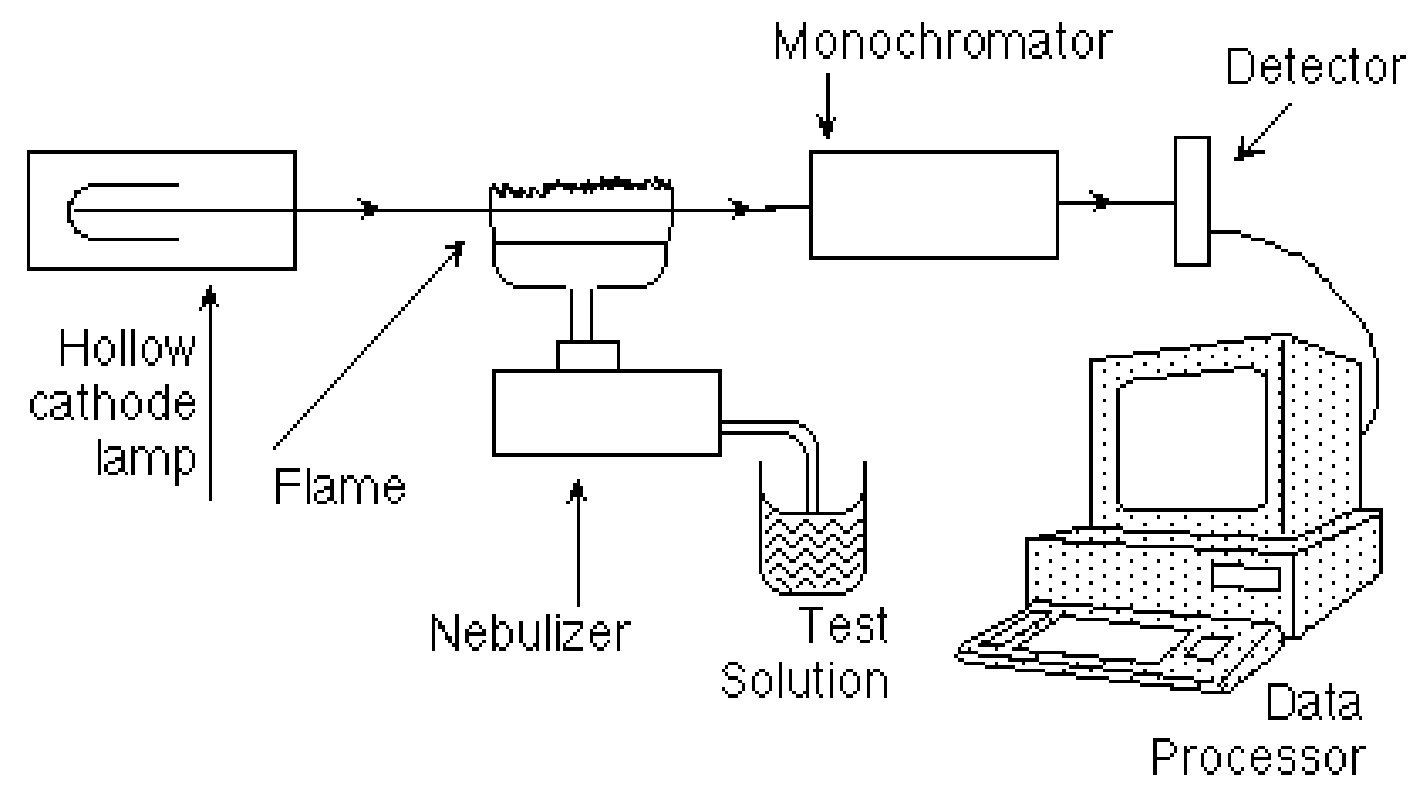

Fig. 2. Schematic diagram of AAS experimental setup. 
The access acids were evaporated during ths process. The deionized water was added to make the total volume of $250 \mathrm{ml}$. Thus the sample was now ready to record the flame atomic absorption record. Similar procedure was adopted for the skin and the flesh. The standard solutions of different concentrations were prepared for different atoms. The corelation curves give the concentration of the sample under investigation.

The atoms for most AA elements cannot exist in the free, ground state at room temperature and therefore heat must be applied to the sample to break the bonds combining atoms in molecules. In flame atomic absorption spectroscopy a liquid sample is aspirated and mixed as an aerosol with combustible gasses (acetylene and air or acetylene and nitrous oxide). The mixture is ignited in a flame of temperature ranging from 2100 to $2800{ }^{\circ} \mathrm{C}$ (depending on the fuel gas used). During combustion, atoms of the element of interest in the sample are reduced to the atomic state.

The characteristic wavelengths are element specific and accurate to 0.01-0.1 nm Line source are lamps that emit very narrow bands of radiation. The most common source is the hallow cathode lamp (HCL). The lamps are encased in a cylinder made of glass and a quart end cap. These cylinders are filled with a noble gas ( $\mathrm{Ne}$ or Ar) to a pressure of 1- 5 torr. The HCLS also contain a tungsten as a anode, a cathode is made of the metal of interest. Lamps of multi element in their cathode are also available. But most FAAS instruments can only measure one element at a time.

To provide element specific wavelengths, a light beam from a lamp whose cathode is made of the element being determined is passed through the flame. A device such as photomultiplier can detect the amount of reduction of the light intensity due to absorption by the analyte and this can be directly related to the amount of the element in the sample. Only those atoms that are the same as those in the lamp will absorb the light from the lamp. A reduction in the amount of light reaching the detector is seen as a measure of the concentration of that element in the original sample.

Table 3. Concentration of different elements in flesh, skin and seed of eggplant fruit.

\begin{tabular}{|c|c|c|c|c|c|c|c|c|c|}
\hline \multirow[b]{2}{*}{$\begin{array}{l}\text { Sample } \\
\text { Description }\end{array}$} & \multicolumn{9}{|c|}{ Parameter } \\
\hline & $\begin{array}{l}\mathrm{Ca} \\
\text { (mg/ } \\
\mathrm{Kg} \text { ) }\end{array}$ & $\begin{array}{l}\mathrm{Cd} \\
\text { (mg/ } \\
\mathrm{kg})\end{array}$ & $\begin{array}{l}\text { Co } \\
\text { (mg/k } \\
\text { g) }\end{array}$ & $\begin{array}{l}\mathrm{Cu} \\
(\mathrm{mg} / \\
\mathrm{kg})\end{array}$ & $\begin{array}{l}\mathrm{Fe} \\
\text { (mg/ } \\
\mathrm{Kg} \text { ) }\end{array}$ & $\begin{array}{l}\mathrm{Mg} \\
\text { (mg/ } \\
\mathrm{kg} \text { ) }\end{array}$ & $\begin{array}{l}\mathrm{Mn} \\
\text { (mg/ } \\
\mathrm{kg})\end{array}$ & $\begin{array}{l}\mathrm{Pb} \\
\text { (mg/ } \\
\mathrm{Kg})\end{array}$ & $\begin{array}{l}\mathrm{Zn} \\
\text { (mg/ } \\
\mathrm{Kg})\end{array}$ \\
\hline $\begin{array}{l}\text { Egg Plant } \\
\text { Flesh }\end{array}$ & 1258 & 2.49 & 9.5 & 8.4 & 63.4 & 1884 & 13.4 & 3.24 & 21.4 \\
\hline $\begin{array}{l}\text { Egg Plant } \\
\text { Skin }\end{array}$ & 1366 & 1.80 & 16.2 & 17.8 & 100.0 & 2065 & 16.9 & 2.44 & 28.4 \\
\hline $\begin{array}{l}\text { Egg Plant } \\
\text { Seed }\end{array}$ & 520 & 2.20 & 8.5 & 19.1 & 123.0 & 2466 & 45.6 & 2.68 & 38.2 \\
\hline
\end{tabular}




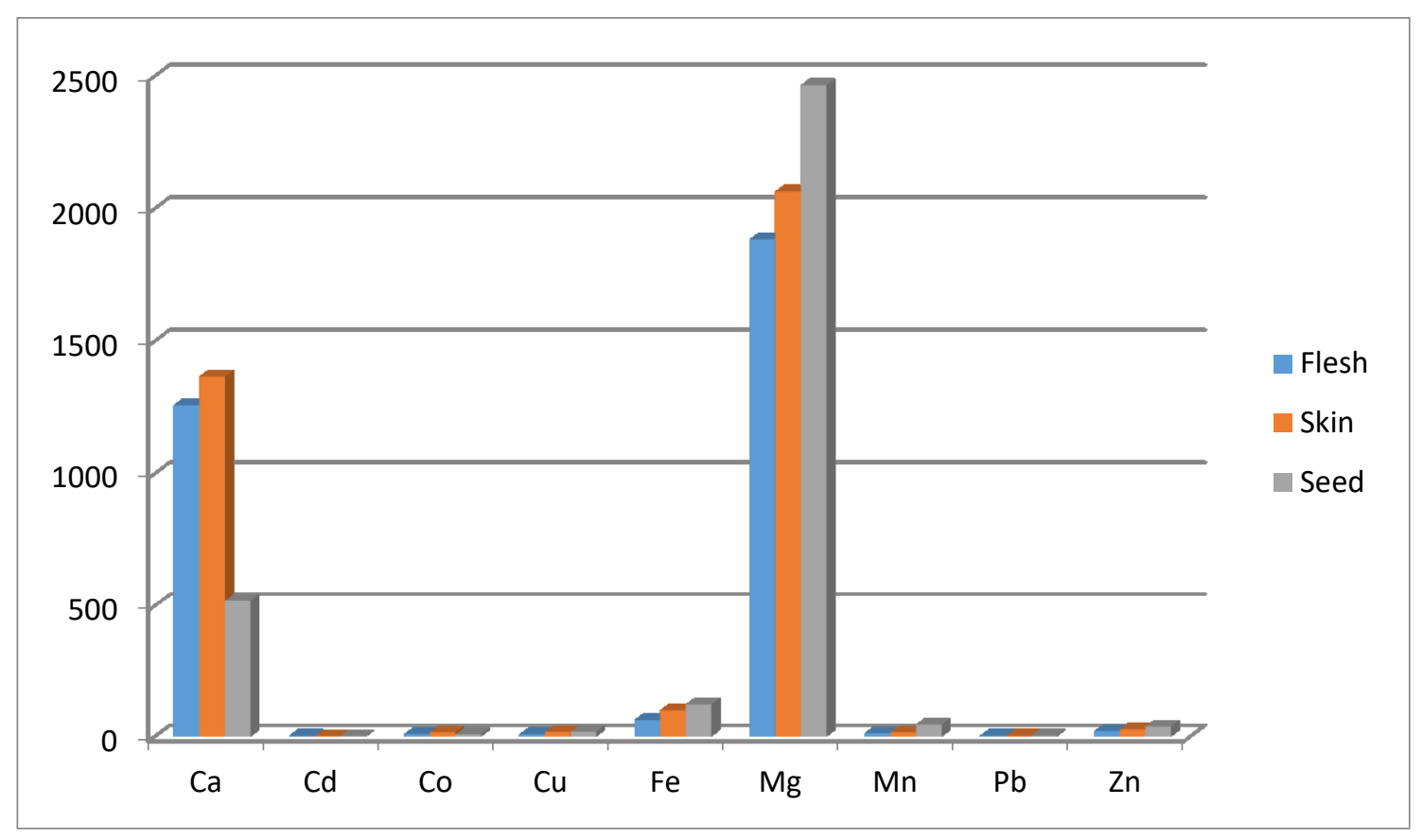

Fig. 3. Showing concentration of different elements in flesh, skin and seed of eggplant fruit.

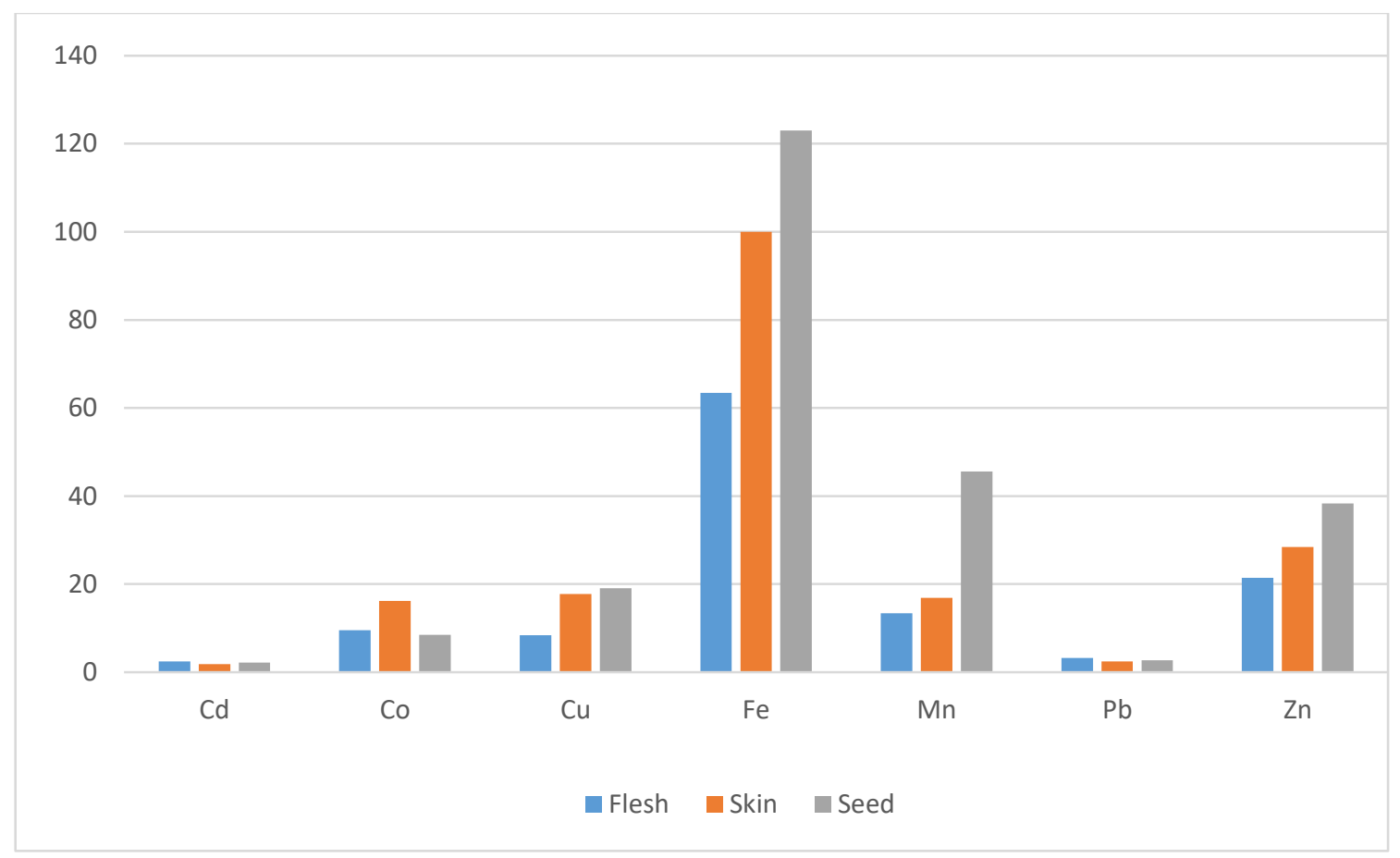

Fig. 4. Showing concentration of elements except magnesium and calcium in eggplant fruit. 


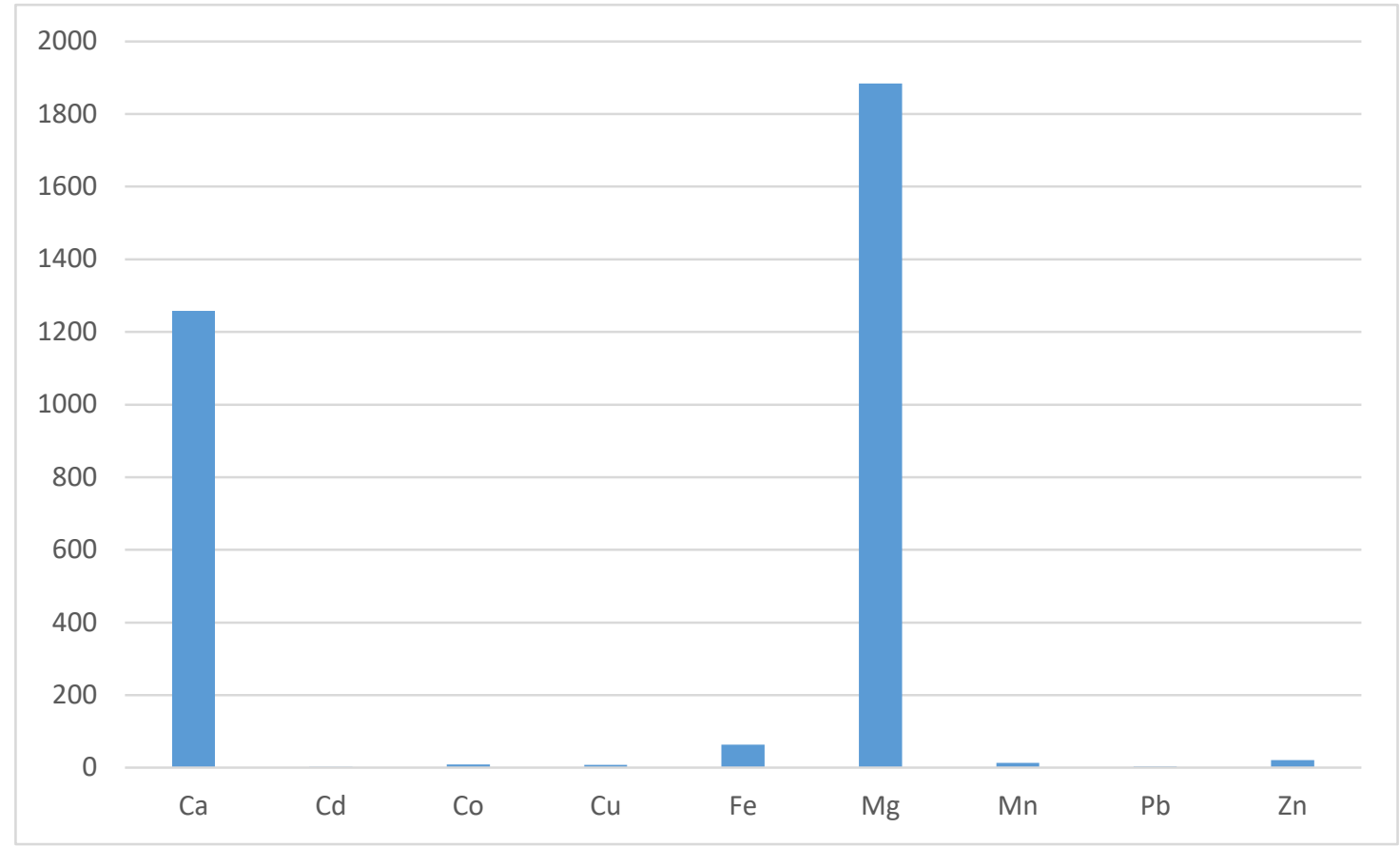

Fig. 5. Showing the concentration of elements in flesh of eggplant fruit.

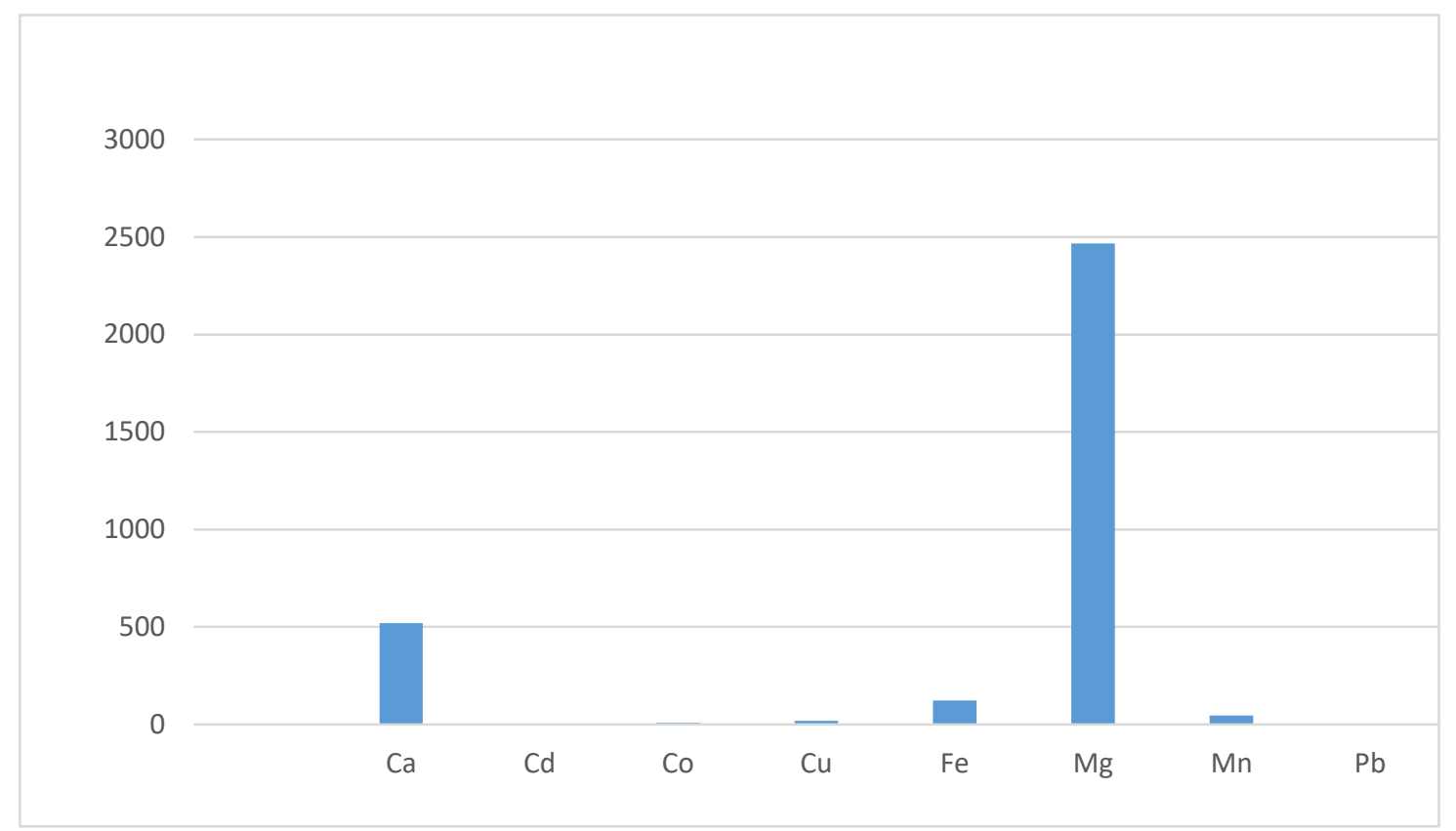

Fig. 6. Showing concentration of element in skin of eggplant fruit. 


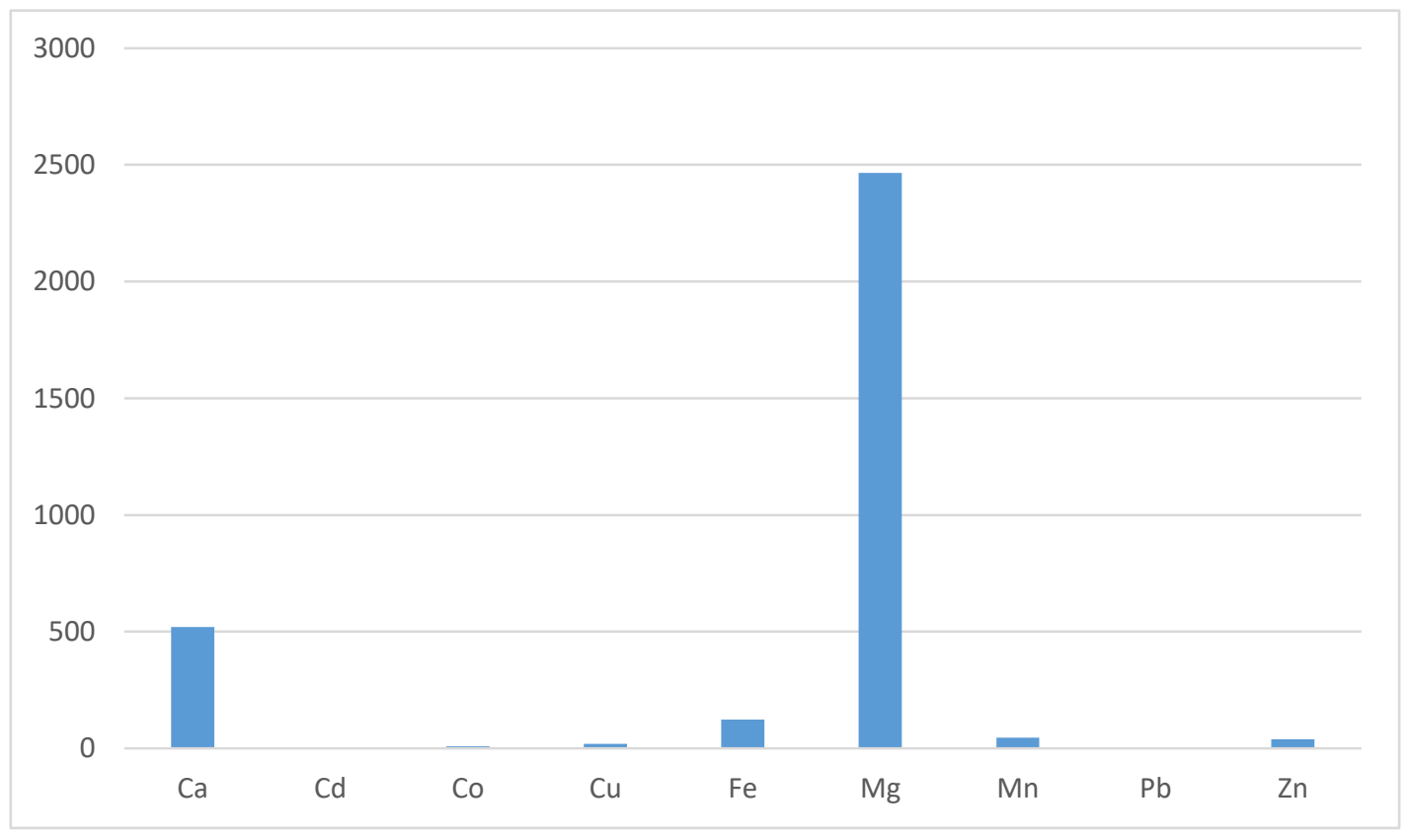

Fig. 7. Showing concentration of elements in seed of eggplant.

\section{RESULT AND DISCUSSION}

\section{1. Description of results of investigations}

Table 2 and the different graphs shown for the data clearly show that the eggplant fruit has the ability to accumulate a quite good amount of calcium as $1258 \mathrm{mg} / \mathrm{Kg}$ in flesh, 1366 $\mathrm{mg} / \mathrm{Kg}$ in skin and $520 \mathrm{mg} / \mathrm{Kg}$ in seed which indicate a good source for human consumption and health as essential for developing and maintaining healthybones and teeth, assists in blood clotting. muscle contraction, nerve transmission, oxygen transport, cellular secretion of fluids and enzyme activity and optimal intake helps to reduce the risk of osteoporosis. Similarly the magnesium which has an importance role as an activator over 100 enzymes and helps nerves and muscles function, maintain the integrity of cell membranes and stabilizes the cell electrically for critical for the heart function has been found in this investigation to a high levels in flesh as $1884 \mathrm{mg} / \mathrm{Kg}, 2065 \mathrm{mg} / \mathrm{Kg}$ in skin and $2466 \mathrm{mg} / \mathrm{Kg}$ in seed and thus the consumption is highly recommended. The other elements are of very little amount and no way harmful in use.

\section{CONCLUSION}

It seems that eggplant fruit is a wonderful fruit provided by nature and can be used without any side effect in general for human beings.

\section{ACKNOWLEDGEMENT}

The basic preparations of the samples were done in our laboratory of the Department of Chemistry where the necessary facilities were arranged. Further the authors are grateful to the staff members of the Analytical Research Laboratory, LBI, GUYSUCO for proving the facilities to record the atomic absorption spectra of the samples. 


\section{References}

[1] C.F. Timberlake, Recent Advances in the biochemistry of fruits and vegetables, New New York Academic Press (1981) 221-247

[2] M.E. Silva, R.C. Santos, M.C. Leary, Brazilian Archives of Biology and Technology 42(3) (1999) 339-342

[3] http://www.whfoods.com/genpage.php?tname=foodspice\&dbid=22

[4] Y. Noda, T .Kneyuki, K. Igarashi, Toxicology 148(2-3) (2000)119-123

[5] B.D. Whitaker, J.R. Stommel, J Agric Food Chem. 51(11) (2003) 3448-3454

[6] E.M. Esteban, E.M. Molla, L.M. Robredo, F.J. Lopez-Andreu, J. Agric. Food Chem. 40(6) (1991) 998-1000

[7] V. Mohabir, V.N. Verma, I.J.A.R. 4 (2012) 199-203

[8] S. Harichan, V.N. Verma, International Letters of Chemistry, Physics and Astronomy 2 (2013) 11-17 